\title{
Environmental ethics on Mount Kelud slopes: Investigating local community responses on the utilization of Mount Kelud materials
}

\author{
A.S.M. Fajar* \\ Institut Agama Islam Tribakti Lirboyo, Kediri, Indonesia
}

A.I. Mawardi

Universitas Islam Negreri Sunan Ampel, Surabaya, Indonesia

A. Syakur

STKIP PGRI Sidoarjo, Indonesia

\begin{abstract}
Anchored by an ethnoecological approach, this study attempted to portray the contradictory situations from both the perspective of natural resources, the use of nature within the framework of an environmental ethics approach, and the cultural cognition that produces the patterns of adaptation from communities around Mount Kelud. Data in this study was gathered from the views of the community around the Kelud slope, which consists of social, religious, cultural and non-governmental organizations. Findings suggest that the existence and meaning of mythology and rituals are in the forms of religiously and locally based friendship life cycles. This study adds to the discussion of environmental ethics and the utilization of Mount Kelud materials in Kediri, East Java, Indonesia.
\end{abstract}

Keywords: environmental ethics, Kelud eruption, land resource

\section{INTRODUCTION}

Indonesia is geographically located along the Pacific Ring of Fire, causing the region to be dominated by active volcanic clusters, making Indonesia vulnerable to volcanic hazards. The presence of volcanoes can be a source of catastrophe that destroys life, especially from the eruptions and the lava. Volcanic eruptions often leave materials from the mountain that can damage plantations, agriculture, settlements, casualties, and other properties (Kelman \& Mather 2008). However, a volcano is a phenomenal landscape that contains ambiguity because, besides being a source of, it is also a source of grace that is beneficial to human life around it, including soil fertility as agricultural and plantation land, a wealth of beneficial sand and stone materials, and the charm of nature with the beauty of the breathtaking mountain panorama (Tjandra 2015). Kelud volcano, which is located between three regencies in East Java province, namely Kediri, Blitar and Malang, is an active volcano that erupts within an interval of about 9-25 years. The explosion tends to be large and quick. The original character of the Kelud volcano is to have a crater lake that can produce a huge amount of lava flows when it erupts, and it is harmful to the surrounding population (Arsana 2014).

The eruption in 2014 showed that the Kelud volcano erupted explosively and in a short time within three hours. The rumbling and the booming sound could be heard as far as the other provinces, and the elevation of the volcanic column was $17 \mathrm{~km}$, thus causing ash rain in the area of Central

*Corresponding author: bbssfwn@gmail.com 
Java and even some areas in West Java. The volcanic ash was even able to paralyze some airports in Java and flight disruption (Yusron 2018). The phenomenon is very different from the Kelud volcano eruption in 2007, beginning with an increase in the seismicity of September 2007. The eruption ended with forming a lava dome in the crater lake on November 3, 2007. This incident was a transition of previously explosive eruption properties to be effusive. On the observation with a GPS method for three sessions in April, August, and October 2008, it was seen that the vector pattern shifting each measuring point is more dominated and influenced by forces that work due to geological structure activities, especially the crustal stabilization phase after the final phase of the eruption in November 2007. The shifts caused by the magma flows are minor and occur only in measuring points that are near the Lava dome with a relatively shallow depth and associated with a seismic zone (Haerani et al. 2010).

The post-eruption of Mount Kelud in 2014 has a significant impact on the building material sector; a large number of river flows upstream on the peak area of the Kelud volcano by carrying large amounts of volcanic material resulting from eruptions has the potential to increase the population's economy (Wardhani et al. 2017). Agricultural conditions were developed by the people of Kediri and Blitar Regencies through planting pineapple plants. Ngancar Sub-district had made the pineapple Festival in October 2016 to introduce this plant to be an "icon" of the Ngancar sub-district. The local residents also dubbed the pineapple in this area a "Pineapple Queen." This is due to the fact that the planting area of this plant in the Ngancar district is more than 2,500 hectares and the production capacity is up to 50 tons/hectare. The tourism sector, which was originally only the peak of Mount Kelud, became several tourist destinations offered at the time of the post-eruption period in 2014. The development of tourist destinations in the lower slope area of Kelud Mountain is rapid as proven with the last three years of opening new tourist destinations located on the lower slope of Mount Kelud in the southwest, including Anggrek Village, Nanas Village in Ngancar District, Teletubies Hill, Karanganyar Coffee Plantation, Melon Village in Nglegok District, Durian Village in Plosoklaten District and Avocado in Puncu and Kepung Dirstrict.

The three significant impacts of the 2014 eruption are activities that are widely undertaken and developed even as a program from the local government as a development capital that emphasizes the wealth of local resources. Thus far, the study of the positive impact of the Mount Kelud eruption has been widely discussed, but the impact and response of local religious and cultural communities to the significance has not been studied. To fill such a void, the present study was designed to reveal fourfold issues: to what extent are local religious and cultural community responses around the slope of Mount Kelud against the significant impact and public understanding of environmental ethics in favor of preserving such significant natural potential through local wisdom and religiosity values, the significant impacts that provide significant benefits for the community and the negative impacts arising from the potential utilization of the landscape after eruption.

\section{METHODS}

In this study, the writer reveals that religion and local wisdom have a major role in the process of understanding the community around the slope of Mount Kelud against environmental ethics. The matters relating to religion and local wisdom are broad and can be grouped into two aspects: a visible aspect and an invisible aspect. Matters relating to religion will be referred to as theological constructions, given that their existence comes from religious teachings. In contrast, the things related to local wisdom can be called cultural constructions because they come from the values of the ancestral heritage of Javanese people on the slopes of Mount Kelud. Each of these constructions is concrete, meaning they can both be seen and observed directly, and there is also an abstract form, meaning it cannot be observed directly. It is stored in the community knowledge system of the slope of Mount Kelud and can only be known by the language phrases. 


\section{RESULTS AND DISCUSSION}

The major problem faced by human beings is the exploitation of natural and environmental resources. Among these cases, this study found that sand mining done by either by an individual or group has been pervasive. The impacts are catastrophic: loss of livelihood, social conflict, environmental pollution disruption of the landscape occur (Sturtevant 2009). This can also be found on the slopes of Mount Kelud. Sand mining done by one company has impacted the destruction of paddy fields and plantations. Looting the land is not only illegal but also eliminates damages plantation operations. Based on law No. 18 the year 2004 on plantations in part two of article 4, the plantation has several functions, such as: economic, which is an increase in prosperity and welfare of the community and the strengthening of the economic structure of the region and country; ecological, which is increase in soil and water conservation, carbon absorption, oxygen production and protected area buffers; socio-cultural, namely as strengthening relations and uniting nations. The occopation of the forest looting and deforestation has lead to the lost of PTPN XII function as the management of state plantations, such function was writen on the provision under LAW No. 18 year 2004. The case can be seen in Afdeling Damarwulan Sepawon Sub-district of Puncu, Kediri Regency The ecological function was vanished due to the logging of hundreds of trees in the location.

There are about 736 types of trees that are felled, consisting of Sengon, Balsa, Mahogany, Gmelina, Johar, Lamtoro, Jabon, Mindi and some other types. The area is a conservation area, where there is a water source flowing to the surrounding villages' residents (Firdaus et al. 2014). One of the impacts of conservation land excavation is the occurrence of landslides. Some parts of areas experience droughts because of water accumulating in certain regions, loss of populations' livelihoods, the destruction of residents dwellings due to massive mining activities and without tolerance of time and place, and sinkholes or the emergence of large holes in the soil as a result of excessive sand dredging. The phenomenon above does not mean to show that the surrounding community is not classified as not having a religion because Kediri is a base of Islamic boarding schools that examines the science of Fiqh (Indiyanto et al. 2012). Besides the practical books of Fiqh, many Islamic boarding schools in Kediri also examined the Fiqh nuances of Sufism, such as the Bidayatul Hidayah book by Imam Ghazali. Al-Ghazali noticed that Sufism and law had to be linked to spiritual life so that there was a close association. The function of public legal law is to regulate relationships between humans. The spiritual function is to discipline a person who has religion and purify his soul at the same time so that a combination of Fiqh and ethics lies in the pressures of heart and identity.

Arguments about the need for research to be done on environmental ethics in the area are departed from two things, first, because the study of Fiqh in an Islamic boarding school is still focused on the aspect of worship and the Mu'amalah (Masburiyah 2011). This statement was acknowledged by the An'im Falahuddin Mahrus, as quoted by Fakhruddin Mangunjaya, as a study of the environment has not been done in the Lirboyo Islamic boarding school, many of his discussions with students and Islamic scholars at Lirboyo are only related to societal issues, apparently, it seems that the environmental problems have not been studied (Mangunjaya 2007; 2014). Even Kyai An'im conveyed on another occasion afterward that environmental preservation is a determinant of natural balance. In the context of environmental preservation, this understanding has been heard for a long time. Even the lesson of natural science seems to unrelentingly teach that all components of the ecosystem, both tangible living beings, and other natural components, are united and must be balanced. However, in the layout of the application, the human must examine and question the effectiveness of the results of existing efforts. Obviously, after realizing such questions, human should introspect on various disaster portraits that have occorred in this hemisphere lately.

The attention to the aspect of environmental ethics that includes an ethical basis together for the people around the slope of Mount Kelud is important in preserving the environment and building public awareness to be committed together in environmental ethics on the slopes of Mount Kelud. Second, because the slope of Mount Kelud is demographically located by the area which 
is surrounded by Christianity, Buddhism, Hinduism and other religious traditions. According to religious adherent data published by the Office of the Ministry of Religion of Kediri Regency, the district and village areas located on the slope of Mount Kelud is a region that has more religions than Muslims when compared to other sub-districts, in the table the sub-districts that are located in the slope of Mount Kelud are: Wates, Ngancar, Plosoklaten, Gurah, Puncu, Kepung, Kandangan and Pare. The following table shows the number of religious adherents in the region (Lukens-Bull 2010).

From the data of environmental ethics among the religious people in the region, the sub-districts and the villages on the slope of Mount Kelud can build harmonious relationships between interfaith religions in forming a joint commitment in preserving the environment around the slope of Mount Kelud. Mount Kelud, for the surrounding community, has a symbolic meaning: first, concerning the aspect of social affairs. In the social context, Mount Kelud for the surrounding community economically gives the blessing of agricultural fertility as the livehihoods of thousands of farmers in the region, including the cultivation of fisheries with the abundant water from the source on the slopes of mountain Kelud (Anshoriy 2008). Therefore, the community of Mount Kelud has a strong bond of existence with Mount Kelud. In addition, Mount Kelud becomes an integral part of establishing the culture of the society. Social order is influenced by symbols that are used as the community's grip in daily life. Then, it will form traditions, values, norms, mythology in the survival of the everyday life of the people around Kelud.

The people around Kelud always carry out various ritual activities, usually lead to a friendly life cycle, such as the birth-related ceremony that began from the pregnancy to the ceremony before the birth of babies, circumcision and pacangan. With regard to death, the people of Kelud also held a traditional Selametan ceremony on days one, three, seven, fourteen, one hundred, and one year and 3 years after his death. Besides that, there are annual ceremonies, such as Muludan, Rejeban, Nisu Sya'ban (Barakah until late night), Ceremony of Nyadran Bulan Ruwah. The ceremonies' uniqueness lies in the rules of the food ingredients that are served, the place of ceremony, and its tools.

In the community belief tradition around Kelud, the older person always becomes a role model, and if they are dead, they are called ancestors. The term ancestor is always associated with the lineage that empties to the opening of the land (the forerunner of the village). The belief of the people around Kelud is the belief in many gods and is usually performed in wayang performances to convey educational and moral messages. In this case, two gods play an important role in society's life, namely the Goddess of fertility or Dewi Sri and Dewa Bathara Kala, who is believed to be able to resist the doom and misery of life.

In the community around Kelud, human interaction between social actors and cultural actors with volcanoes as a venue for socio-cultural activities has its background. Mount Kelud is an integral component of the surrounding community, both from the ecological system, the socio-cultural system, and territorial integrity. Despite the repeated disasters of Mount Kelud in Kediri and Blitar, the choice to settle in the volcanic area is not to be rethought. Generatively, the experience of interacting with the volcanic environment and making a community around Kelud can be friendly with the character of Mount Kelud, and they do not avoid it. Nevertheless, those living in the volcanic area remain wary that they live amid the disaster's potential insecurity.

In the Hindus' view, one form of intensive relationship with the mountain is to purify the mountain and pack it in a magical fashion by regularly worshipping the mountain ruler. The ruler of Kelud volcano is Hyang Acalapati or Dewa Acalapati, a mountain deity that existed only in Java and this deity also resides on Kelud. The kingdom of Kediri built Penataran Temple to worship the Lord of the Kelud so as not to anger him and to release his fire. In the era of the Majapahit kingdom, Raja Hayam Wuruk worshipped this deity in Candi Penataran. With the belief that Mount Kelud is a place of worship of the gods, society uses religious-magical mitigation to ward off fiery Kelud eruptions. This approach is more dominant than technological or engineering mitigation. This belief can be seen in Besowo village, Kepung District Kediri Regency. The people of this village still held ritual adoration of Kelud volcano. This adoration is known as Argakerti or mountain ceremonies. 
This cult was created because the Kelud volcano had an important position. Kelud volcano is included in the Pancamahabuta or five important natural particles besides earth, oceans, lakes, and rivers. This cult was led by Pandita Ida Pandita Wesnamatwaja. The village of Besowo, whose majority of its citizens embraced Hinduism, always gave offerings in every Argakerti ceremony, such as the head of black buffalo and others. The Argakerti cult ceremonies are held as offerings to the Sanghiang Giri Pati or those who bring the mountain to life. In the Kelud volcano, there is also Sanghiang Acalapati, which is part of Kelud. The offerings to the two gods were intended so that the fire in Kelud would not flare up but also did not extinguish. In Penataran Temple held ceremonies worship for Sanghiang Acalapati, and in the village Besowo, District Kepung Kediri Regency, held ceremonies worship Sanghiang Giri Pati. The two ceremonies are done so that the Kelud volcano remains in a stable position.

People who are living in the area of Gunung Kelud have legendary folklore that is closely related to the existence of the mountain, such as; some people believe that the eruption occurred because of the anger of Mahesa Sura to the daughter of Kediri named the Dewi Kili Suci. The character is closely related to the legend of Panji as folklore that thrives in Kediri. It is said that Mahesa Sura, a powerful knight with a buffalo head fell in love and submitted a proposal to the Dewi Kili Suci. The proposal woukd be accepted by the princess if the suggestion was fulfilled, which was to make a large and deep well. Mahesa Sura was trapped and fell into the stone well. By the command of the princess, her troops pelted Mahesa Sura with a lot of rocks so that the well became a giant mound resembling a mountain. This story became the legend of Mount Kelud. Blitar people believe the story so that they think the eruption of Kelud will not significantly impact Blitar because the anger of Mahesa Sura leads to Kediri. Wage Keramat; wage is one of the market days in the Java Calendar system (Pahing, Pon, Kliwon, and Legi). People who believe in Titen (memory) science, believe that it is still valid in their daily lives and that Gunung Kelud will erupt on the day of the Wage market. Mount Kelud is a cemetery for the Keris Empu Gandring.

During the heyday of Majapahit Kingdom under the ruler of King Hayam Wuruk Gunung Kelud erupted. The eruption had a great impact and gained the attention of the king, since its impressiveness was considered able to muzzle the evil aura of the Kris Empu Gandring. During the Wisnuwardana period, the Keris was discarded in the crater Mount Kelud. The Larung Saji for rejecting disaster: People of Sugihwaras village, Ngancar district, Kediri Regency in each month of Suro always hold a ritual of the offering ceremony to reject the oath of Mahesa Sura (Lembu Sura). Some people also assume that this ceremony is a blessing form on the fertility of the Kelud Land (subur gemah ripah loh jiwani) and a tribute to the ruler of Mount Kelud. The Christian community in Gunung Kelud believes that Tunggul Wulung is legendary in Kediri and especially on Mount Kelud. It is believed to be the warlord of King Jayabaya who ruled the Kediri kingdom. In the narration of Serat Babad Kadhiri, written by Mas Ngabehi Poerbawidjaja and Mas Ngabehi Mangoenwidjaja, after completing his service for Prabu Jayabaya, Tunggul Wulung chose to be a demon that was commanded to stay and guard Mount Kelud against all dirty and wicked deeds.

In the current development of the Christian community in the slope of Mount Kelud, they build environmental ethics after the eruption with the establishment of the Program Pengembangan Desa Bersaudara, which means "The Village Brothers Development Program" or in commonly used the English words, "Sister Village." Which can simply can be interpreted as an effort to bring together a village that is in a disaster-prone area with villages that are in a safe area cooperate in disaster management. The movement can be found in the Sempu-Ngancar village, Segaran village, corner Wates village and Besowo village of the Kepung subdistrict. These villages contain the majority of Christians, namely Segaran village and the corner village of Wates District, and Damarwulan Village of Kepung Sub-district and Sidorejo village of Pare district. The term Sister is a popular phrase in the Dutch Colonial Hospital System that is often used by the church.

In the condition of gugur gunung or when the slope of Mount Kelud bestows the grace of potential natural resources, a sister village can be developed sustainability in developing cooperation and strengthening capacity and resources. For example, in the economics fields and foods, where one of the villages in an area that does not produce rice, it can cooperate with the production area and 
rice barn. Through BUMDes and farmer groups, the community can obtain good rice quality at affordable prices because it is directly from the farmer's production. Other advantages gained from this cooperation involve the farmer group and BUMDes, where much money circulates. Hence, the economic activity of the community can increase. The wider impact is that society can be more resilient food in the face of catastrophic potential (Yusron 2018).

\section{CONCLUSION}

This study has revealed the religiously and locally-based existence and meaning of mythology and rituals among Mount Kelud communities. Local community responses to the utilization of Gunung Kelud material can be found in various forms of collaboration between communities, such as various ritual activities that have always been carried out by the community around Kelud, usually based on a friendship life cycle. The community of Islamic boarding schools around Mount Kelud, represented explicitly by Lirboyo Islamic boarding school and other surrounding schools, has conducted an in-depth study of the classical Fiqh books implemented in the ethics environment. Hindu Society implements a form of intensive relationship with the mountain to cleanse the mountain and pack it magically, by regularly holding worship of the mountain rulers.

\section{REFERENCES}

Anshoriy, Nasruddin M. Ch. 2008. Kearifan lingkungan dalam perspektif budaya Jawa. Jakarta: Yayasan Obor Indonesia.

Firdaus, Maulana, Radityo Pramoda, \& Maharani Yulisti. 2014. Dampak Letusan Gunung Kelud Terhadap Pelaku Usaha Perikanan Di Kabupaten Kediri, Provinsi Jawa Timur. Jurnal Kebijakan Sosial Ekonomi Kelautan dan Perikanan 4, no. 2: 157.

Haerani, Nia, Hendrasto, M., \& H. Z. Abidin. 2010. Deformasi Gunung Kelud Pascapembentukan Kubah Lava November 2007. Indonesian Journal on Geoscience 5, no. 1: 13-30.

Indiyanto, Agus, \& Arqom Kuswanjono, ed. 2012. Kajian integratif ilmu, agama, dan budaya. Cet. 1. Seri agama dan bencana. Bandung: Kerja sama Mizan Pustaka [dan] Program Studi Agama dan Lintas Budaya, Sekolah Pascasarjana, Universitas Gajah Mada, Yogyakarta.

Kelman, Ilan, \& Tamsin A. Mather. 2008. Living with Volcanoes: The Sustainable Livelihoods Approach for Volcano-Related Opportunities." Journal of Volcanology and Geothermal Research 172, no. 3-4: 189-98.

Lukens-Bull, Ronald. 2010. Madrasa by Any Other Name: Pondok, Pesantren, and Islamic Schools in Indonesia and Larger Southeast Asian Region. Journal of Indonesian Islam 4, no. 1: 1-21-21.

Mangunjaya, Fachruddin M. 2014. Ekopesantren: bagaimana merancang pesantren ramah lingkungan? Cetakan pertama. Jakarta: Yayasan Pustaka Obor Indonesia.

Mangunjaya, Fachruddin M., ed. 2007. Menanam sebelum kiamat: Islam, ekologi, dan gerakan lingkungan hidup. Ed. 1. Jakarta: Conservation International Indonesia: Islamic College for Advanced Studies.

Masburiyah. 2011. Konsep Dan Sistimatika Pemikiran Fiqih Sufistik Al-Ghazali." Nalar Fiqh 4, no. 1.

Nyoman, Arsana. 2014. Dedikasi TNI dalam bencana Sinabung dan Kelud, Jakarta: Pusat Sejarah, Markas Besar Tentara Nasional Indonesia.

Sturtevant, William C. 2009. Studies in Ethnoscience1. American Anthropologist 66, no. 3: 99-131.

Tjandra, Kartono. 2015. Mengenal gunungapi: bencana dan manfaat hasil letusannya. Cetakan pertama. Yogyakarta: Gadjah Mada University Press.

Wardhani, Puspita Indra, Junun Sartohadi, dan Sunarto Sunarto. 2017. Dynamic Land Resources Management at the Mount Kelud, Indonesia. Forum Geografi 31, no. 1: 56.

Yusron. 2018. Menguak pesona Gunung Kelud, 1st edition. Yogyakarta: deepublish. 


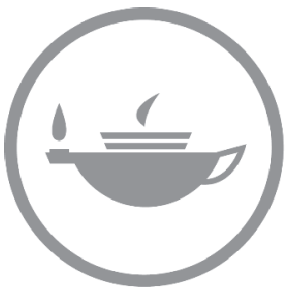

Taylor \& Francis Taylor \& Francis Group

http://taylorandfrancis.com 